\title{
MPP3 wt Allele
}

National Cancer Institute

\section{Source}

National Cancer Institute. MPP3 wt Allele. NCI Thesaurus. Code C51060.

Human MPP3 wild-type allele is located within 17q12-q21 and is approximately $32 \mathrm{~kb}$ in length. This allele, which encodes MAGUK p55 subfamily member 3 protein, is involved in coupling the cytoskeleton to the cell membrane and plays a putative role in signal transduction. 